\title{
Amino acids profile and protein functional properties of Chrozophora oblongifolia seeds from Kordofan Region, Sudan
}

\author{
SULEIMAN IBRAHIM ABAKER ABDALGADER, ADAM ISMAIL AHMED \\ Department of Food Science and Technology, Faculty of Natural Resources and Environmental Studies, University of Kordofan. P.O. Box .160, Elobeid, \\ Kordofan, Sudan. •email: adamalgnana62@yahoo.com
}

Manuscript received: 31 January 2019. Revision accepted: 7 March 2019.

\begin{abstract}
Abdalgader SIA, Ahmed AI. 2019. Amino acids profile and protein functional properties of Chrozophora oblongifolia seeds from Kordofan Region, Sudan. Trop Drylands 3: 17-21. Species of Chrozophora genus (Euphorbiaceae family) have been traditionally used as food with many of these species showing high content of protein and oil with high percentages of fatty acids. The present research was conducted to study the amino acids profile and protein functional properties of Chrozophora oblongifolia seeds. The fresh seeds samples were obtained from North and West Kordofan regions, Sudan. The protein functional properties, i.e., water absorption capacity, oil absorption capacities, emulsifying capacity, foaming stability, bulk density and crude protein were determined, then the amino acids profile was investigated using an amino acids analyzer (L-8900 Hitachi-Hitech, Tokyo, Japan) under the experimental conditions recommended for protein hydrolysates. There were seven essential amino acids namely lysine, histidine, threonine, methionine, valine, isoleucine and phenylalanine, and nine non-essential amino acids namely arginine, aspartic acid, serine, glutamic acid, glycine, proline, alanine, cysteine and tyrosine. Glycine with a range of 0.99-1.02 g/100g proteins, while arginine with a range of 8.43-8.87 g/100g protein was the highest. Leucine and isoleucine, which were limiting amino acids in most foodstuffs, were in ranges of 7.27-7.59g/100g and 5.24-56 4.19 g/100g, respectively. Statistical analysis of the seeds protein concentrates showed that significant differences $(\mathrm{p} \leq 0.05)$ in crude protein and water absorption capacities, oil absorption capacities, foaming stability and bulk density were found between the two different collection regions, while there were no significant $(\mathrm{p} \leq 0.05)$ differences found in emulsifying capacity and foaming capacity. The protein concentrates indicated higher protein content for North Kordofan seeds (83.33\%) than that of $80.6 \%$ for West Kordofan seeds. This study concluded that $C$. oblongifolia seeds can be considered as a cheap source of edible protein which had rich of essential amino acids
\end{abstract}

Keywords: Amino acids profile, functional properties, Chrozophora oblongifolia seeds, Kordofan region, Sudan

\section{INTRODUCTION}

Plants have been used for thousands of years to flavor and conserve food, treat health disorders and prevent diseases. Species of Chrozophora genus (Euphorbiaceae family) are distributed in West Africa and Asia and they are monoecious, shrubby herbs and annual plants. Their leaves, stems and fruits have been used in food and traditional medicine for the treatments of infectious diseases; many of these species showed high content of protein and oil with high percentages of fatty acids (Ahmed et al. 2014). The biological activity of the Chrozophora plants received increased attention to discover new leading compounds for treatment of diverse ailments (Galal and Adam 1988).

Methanol extracted from the parts of Chrozophora oblongifolia showed highest antioxidant and hepatoprotective activities, and it had a valuable biological source of drugs that enhances fertility (Kamel et al. 2018). In 1995, a study was conducted at Safiola company-Sudan to screen the seeds oil characteristics. Results showed that it has $0.29 \%$ moisture, $2.7 \%$ free fatty acids, $1.9 \mathrm{mq} / \mathrm{kg}$ peroxide value, $102.9 \mathrm{~g} / 100 \mathrm{~g}$ iodine value close to cottonseed and rapeseed oils. Also, the trace metals contents were within the normal limit, and its refining and bleaching behaviors were very similar to other normal vegetable oils (Galal and Adam 1988).

Thus, the industrial potentiality of Chrozophora oil should be explored. Therefore, exploitation of Chrozophora seed as alternative source of proteins and oil need to be investigated. The aim of present work was to analyze amino acids profile and investigate protein functional properties of seeds of $C$. oblongifolia plant.

\section{MATERIALS AND METHODS}

\section{Plant materials}

The fresh seeds of $C$. oblongifolia were collected from two different locations from West and North Kordofan States, Sudan. The plant materials were air-dried in the laboratory and then ground into powder form using a mortar, shieved, and then stored in air-tight bottles pending the analyses.

\section{Amino acids analysis}

The amino acid content (except for tryptophan) in the seeds of $C$. oblongifolia plant was determined using an amino acid analyzer (L-8900 Hitachi-Hitech, Tokyo, Japan) under the experimental conditions recommended for protein hydrolyzates. Samples containing $5.0 \mathrm{mg}$ of protein were acid hydrolyzed with $1.0 \mathrm{ml}$ of $6 \mathrm{~N} \mathrm{HCl}$ in vacuum- 
sealed hydrolysis vials at $110^{\circ} \mathrm{C}$ for $22 \mathrm{~h}$. Ninhydrin was added to the $\mathrm{HCl}$ as an internal standard. The tubes were cooled after hydrolysis, opened and placed in a desiccator containing $\mathrm{NaOH}$ pellets under vacuum conditions until dry (5-6 days). The residue was then dissolved in a suitable volume of $\mathrm{NaS}$ buffer, $\mathrm{pH} 2.2$ filtered through a Millipore membrane $(0.22-\mathrm{lm}$ pore size, Millipore, Billerica, MA, USA) and analyzed for amino acids by ion-exchange chromatography in a Beckman (model 7300, Pickering Laboratories, Inc. Mountain View, CA, USA) instrument, equipped with an automatic integrator. Amino acid nitrogen was determined by multiplying the concentration of individual amino acids by corresponding factors calculated from the percentage $\mathrm{N}$ of each amino acid (Mosse 1990). The ammonia content was included in the calculation of protein nitrogen retrieval, as it comes from the degradation of some amino acids during acid hydrolysis (Yeoh and Truong 1996; AOCS 1993). The ammonia nitrogen content was calculated by multiplying the ammonia content by $0.824\left(\mathrm{~N}=82.4 \% \mathrm{NH}_{3}\right)$.

\section{Amino acids calculation}

The amount of amino acid obtained was calculated $(\mathrm{g} / 100 \mathrm{~g})$ by the formula:

$$
X=\frac{\text { Area of Asp in the sample X Area of internal std (AABA) Xamount of std X dilution factor }}{\text { Area of Asp std X Area of sample internal std X sample weight }}
$$

Where:

$\mathrm{X}=$ represents the amount of amino acid $(\mathrm{g} / 100 \mathrm{~g})$

\section{Preparation of Chrozophora oblongifolia seeds protein concentrate}

Protein was extracted from $C$. oblongifolia protein concentrate using alkali solution with isoelectric precipitation and freeze-drying. The dried defatted seeds were weighed and suspended in distilled water in 1:10 (w/v) ratio using magnetic stirrer, the mixture was stirred for 1 hour, while adjusting the $\mathrm{pH}$ at 9.0 using sodium hydroxide $\mathrm{NaOH}$ solutions $(4 \mathrm{M})$. Then, the mixture was centrifuged at $3500 \mathrm{rpm}$ for 15 minutes at ambient temperature. The supernatant was transferred into a beaker and stirred for another 30 minutes and the $\mathrm{pH}$ was adjusted to 4.5. The supernatant was left undisturbed for cold precipitation overnight in $4^{\circ} \mathrm{C}$ freezers. After that, the supernatant was carefully siphoned off and the protein slurry was washed 3 times with distilled water by adding distilled water and centrifuging at 3500rpm for 10 minutes at $4{ }^{\circ} \mathrm{C}$. The pellets were then mixed together and some distilled water was added in there. The $\mathrm{pH}$ was adjusted at 7.0. The slurry was kept overnight inside $-80^{\circ} \mathrm{C}$ freezer before it was freeze-dried (Chandi and Sogi, 2007). The sample inside the freeze dryer took 2 to 3 days before it was completely dried. The protein concentrates obtained from seeds were weighed using analytical balance.

\section{Crude protein content}

The crude protein content was determined in protein concentrate of $C$. oblongifolia plant seeds by macro-
Kjeldahl method according to the official methods analysis (AOAC 2005).

\section{Functional properties of protein concentrate}

Water absorption capacity: The water absorption capacity was determined according to method described by Jyothirmayi et al. (2006) as follows: Only $0.1 \mathrm{~g}$ of $C$. oblongifolia protein concentrate was taken from the sample mixed with $1 \mathrm{ml}$ of distilled water. The slurry was centrifuged at $3000 \mathrm{rpm}$ for 15 minutes. The supernatant was removed, then the pellets were drained for 30 minutes and the gain weight per unit weight was reported as water absorption capacity $(\mathrm{g} / \mathrm{g})$.

Oil absorption capacity: One gram of $C$. oblongifolia protein concentrate was mixed with $10 \mathrm{ml}$ of refined sunflower oil, vortex thoroughly, and centrifuged at 3000 rpm for 15 minutes. The oil absorbed by the samples was noted and expressed as oil absorption capacity (g/g) (Beuchat 1977).

Foaming capacity and foam stability: Foaming capacity of $C$. oblongifolia protein concentration was determined by measuring the volume of foam immediately after the introduction of air $\left(90 \mathrm{~cm}^{3} / \mathrm{min}\right)$ for 15 seconds into $5 \mathrm{ml}$ of $0.2 \%$ protein solution in $0.05 \mathrm{M}$ phosphate buffer $(\mathrm{pH} 7.4)$ (Kato 1989). Foam stability was calculated using the following equation:

$$
\mathrm{FS}=\mathrm{V} 0(\Delta \mathrm{t} / \Delta \mathrm{V})
$$

Where F: foaming, $\mathrm{S}$ : stability, $\Delta \mathrm{V}$ : the change in the volume of foam $(\mathrm{V})$, occurring during the time interval, $\Delta \mathrm{t}$ (30 $\mathrm{min})$, and V0 is the volume of foam at 0 time.

Emulsifying capacity: For the determination of emulsifying capacity, $50 \mathrm{~g}$ of protein suspension were transferred into a blender vat and the sunflower oil was added, under continuous mixing until the emulsion was destroyed (Beuchat, 1977). Measurements were performed at $22 \pm 11^{\circ} \mathrm{C}$ and the emulsifying capacity was expressed as $\mathrm{ml}$ of oil used for the emulsification of $1 \mathrm{~g}$ of $C$. oblongifolia protein derivatives.

Bulk density: The bulk density was determined according to the methods outlined by Okaka and Potter (1977). Ten grams of protein isolate were put into $100 \mathrm{~mL}$ measuring cylinder, then tapped several times on the laboratory bench till the isolate stopped settling, the values were expressed as $\mathrm{g} / \mathrm{cm}^{3}$.

\section{RESULTS AND DISCUSSION}

\section{Amino acids profile}

Most of the amino acids were found to be presence in C. oblongifolia seeds samples investigated except tryptophan (Table 1). A total of 17 amino acids consisting of eight essential, namely lysine, histidine, threonine, methionine, valine, isoleucine, leucine, and phenylalanine and non-essential amino acids namely arginine, aspartic acid, serine, glutamic acid, glycine, proline, alanine, cysteine and tyrosine are presented in Table 1. The highest 
value of essential amino acids found in North Kordofan region seeds was leucine, isoleucine and valine, while the highest value of essential amino acids of $C$. oblongifolia seeds in West Kordofan was leucine, isoleucine, valine and threonine. On the other hand, the lowest values of essential amino acids from both samples were histidine and methionine. Non-essential amino acids arginine, alanine and aspartic acid from C. oblongifolia seeds in North and West Kordofan had the highest value compared to the lowest values of serine, glycine, glutamic acid, tyrosine, and cysteine from both samples' regions. The amino acid with the least concentration was glycine with a range of $0.99-1.02 \mathrm{~g} / 100 \mathrm{~g}$ proteins, while arginine with a range of 8.43-8.87 $\mathrm{g} / 100 \mathrm{~g}$ protein was the highest (Table 1).

The ranges of essential amino acids obtained from the different locations of $C$. oblongifolia seeds samples in present study were in agreement with Chrozophora brocchiana seeds amino acids reported by Ahmed (2014) and also was within the same range for reference pattern protein by FAO (1981) standards which were indicated for leucine and isoleucine. These were limiting amino acids in most feedstuffs that were presently ranging from $7.03 \mathrm{~g} / 100 \mathrm{~g}$ protein for leucine and $4.19 \mathrm{~g} / 100 \mathrm{~g}$ protein for isoleucine in those mentioned in the FAO standards. The value of essential amino acids concentration obtained in this study was in line with Ahmed (2014) who showed that C. oblongifolia had higher protein contents of essential amino acids such as leucine, isoleucine, and valine. The results of this study showed that the protein of $C$. oblongifolia seeds had higher quantity of amino acids such as arginine, alanine leucine, aspartic acid, isoleucine, and valine.

Table 1. Amino acids profile $(\mathrm{g} / 100 \mathrm{~g}$ crude protein) of $C$. oblongifolia seeds

\begin{tabular}{lcc}
\hline \multirow{2}{*}{ Amino acid } & \multicolumn{2}{c}{ Samples source } \\
Essential & & West Kordofan \\
Lysine & 2.31 & 3.23 \\
Histidine & 1.80 & 1.16 \\
Threonine & 3.16 & 3.87 \\
Valine & 4.13 & 5.33 \\
Methionine & 1.02 & 1.91 \\
Isoleucine & 5.24 & 5.56 \\
Leucine & 7.27 & 7.59 \\
Phenylalanine & 3.12 & 3.57 \\
Non-essential & & \\
Aspartic Acid & 6.11 & 6.74 \\
Alanine & 8.10 & 7.23 \\
Serine & 1.46 & 1.03 \\
Tyrosine & 1.09 & 1.04 \\
Glutamic Acid & 1.51 & 1.75 \\
Glycine & 1.02 & 0.99 \\
Ammonia & 6.21 & 6.32 \\
Arginine & 8.43 & 8.87 \\
Cysteine & 1.65 & 1.55 \\
Proline & 3.02 & 2.97 \\
\hline
\end{tabular}

\section{Protein content of the concentrates}

Protein contents in that protein concentrate had a high amount in both North and West Kordofan regions which were 83.33 and $80.66 \%$, respectively (Table 2). The variations in protein contents of different protein isolates could possibly be due to extent of soluble proteins present in raw materials. The variations in protein contents are attributed to genetic makeup of the sources of proteins along with some environmental factors. The proteins known as polymers of amino acids and their relatives' proportion represent its quality that is dependent on genetic makeup of sources of proteins such as (legumes). This result is similar to some legumes such as pea protein concentrate of $83.61 \%$ and pigeon pea of $82.92 \%$ which were reported by the above mentioned authors (Masood and Rizwana 2010).

\section{Functional properties \\ Water and oil absorption capacity}

Seeds protein concentrates obtained from North Kordofan seeds exhibited water absorption capacity of 2.9 $\mathrm{g} / \mathrm{g}$, and West Kordofan seeds protein was absorbed 2.26 $\mathrm{g} / \mathrm{g}$ (Table 2). However, these values were higher than 1.45 for peanut powder reported by Monteiro and Prakash (1994). On the other hand, this value is in agreement with the $2.62 \mathrm{~g} / \mathrm{g}$ in mung bean protein concentrates revealed by $\mathrm{Du}$ et al. (2018). Therefore, the protein concentrates obtained from defatted $C$. oblongifolia seeds had low water absorption, but are still considered high in the range of water absorption capacity of glutinous food, while the oil absorption capacity of protein concentrate was $3.73 \mathrm{~g} / \mathrm{g}$ for North Kordofan seed oil and $3.13 \mathrm{~g} / \mathrm{g}$ for West Kordofan seeds oil. The low value of oil absorption may be attributed to the presence of large proportion of hydrophilic groups and polar amino acids on the surface of the protein molecules (Sathe et al. 1982). Protein has both hydrophilic and hydrophobic properties, thereby can interact with water and oil in food. The varied values of WAC might be due to the protein structure and amount of polar amino acids, whereas the OAC difference might be due to the difference in nonpolar side chains binding the oil (Yi-Shen 2018).

\section{Emulsion absorption capacity}

The emulsion absorption, for both samples, revealed almost a similar absorption rate of $3.33 \mathrm{~g} / \mathrm{g}$ for North Kordofan protein concentrates and $3.00 \mathrm{~g} / \mathrm{g}$ for West Kordofan protein concentrates. Results are comparable to the earlier findings of Bugis (2009) who reported a value of $1.32 \mathrm{~g} / \mathrm{g}$ emulsion absorption for lupine protein isolates. These findings are in line with Makri et al. (2005) who stated that protein being the surface-active agent can form and stabilize the emulsion by creating electrostatic repulsion on oil droplet surface. 
Table 2. Protein functional properties of Chrozophora oblongifolia seeds

\begin{tabular}{lll}
\hline \multicolumn{1}{c}{ Parameter } & \multicolumn{1}{c}{$\begin{array}{c}\text { North } \\
\text { Kordofan }\end{array}$} & \multicolumn{1}{c}{$\begin{array}{c}\text { West } \\
\text { Kordofan }\end{array}$} \\
\hline Protein content \% & $(83.33) \mathrm{a} \pm 1.52$ & $(80.66) \mathrm{b} \pm 1.52$ \\
Water absorption capacity g/g & $(2.90) \mathrm{a} \pm 0.10$ & $(2.26) \mathrm{b} \pm 0.25$ \\
Oil absorption capacity g/g & $(3.73) \mathrm{a} \pm 0.25$ & $(3.13) \mathrm{b} \pm 0.15$ \\
Emulsion absorption g/g & $(3.33) \mathrm{a} \pm 0.25$ & $(3.00) \mathrm{a} \pm 0.10$ \\
Foaming capacity \% & $(21.66) \mathrm{a} \pm 0.57$ & $(20.00) \mathrm{a} \pm 1.00$ \\
Foaming stability g/ml & $(2.33) \mathrm{b} \pm 1.52$ & $(2.43) \mathrm{a} \pm 1.52$ \\
Bulk density g/cm3 & $(0.73) \mathrm{a} \pm 0.04$ & $(0.56) \mathrm{b} \pm 0.05$ \\
\hline
\end{tabular}

Note: *All Determinations were carried out in triplicate and mean value \pm standard deviations (SD). Means not sharing superscript letters in a column were significant different

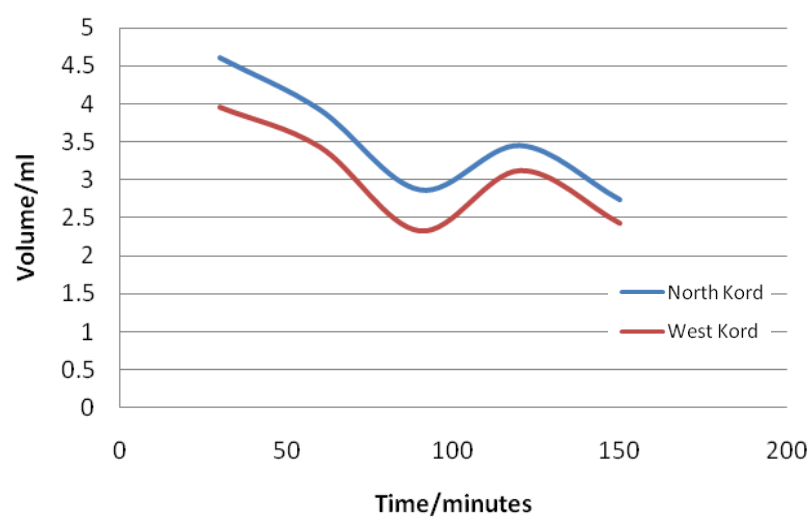

Figure 1. Foaming stability of protein concentrate of Chrozophora oblongifolia seeds

\section{Foaming capacity and stability}

Foaming capacity of protein concentrates of North Kordofan and West Kordofan seeds was $21.66 \%$ and $20 \%$, respectively, where it reached a maximum at $\mathrm{pH} 9$. The foaming capacity of both locations of protein concentrates was affected by $\mathrm{pH}$ and it tended to decrease as $\mathrm{pH}$ decreased. The same trends were found in foaming stability. The foaming stability of North Kordofan protein was reported at a time of 30,60, 90, 120 and 150 minutes were $4.60,3.92,3.43,2.87,2.33 \mathrm{~g} / \mathrm{ml}$, respectively, for the same mentioned times the West Kordofan protein was 3.95, $3.45,3.12,2.74$ and $2.43 \mathrm{~g} / \mathrm{ml}$, respectively (Figure 1). The foaming capacity of $C$. oblongifolia protein concentrates in present investigation was found to be lower value when compared with the results of the commercial protein for albumin studied by Moharram et al. (1984), while the foaming capacity declined due to several factors, including the source and composition of protein as well as the temperature and the solubility (Jasim 1983).

\section{Bulk density}

The bulk density of protein concentrates from two different regions of North Kordofan and West Kordofan seeds were found to be $0.73 \mathrm{~g} / \mathrm{cm}^{3}$ for North Kordofan and $0.56 \mathrm{~g} / \mathrm{cm}^{3}$ for West Kordofan (Table 2). These results were in agreement with Masood and Rizwana (2010) who reported a value of $0.71 \mathrm{~g} / \mathrm{cm}^{3}$ for bulk density of legumes protein isolates.

In conclusion, the amino acid with the lowest concentration was glycine, while arginine had the highest value found in the two different production regions. The range of essential amino acids obtained in this study was within the same range for reference pattern protein required by FAO standards especially leucine and isoleucine which were limiting amino acids in most feedstuffs. This study investigated the nutritional value of $C$. oblongifolia seeds as a cheap source of edible protein which had rich in essential amino acids. Characterization of the properties of protein concentrates obtained from $C$. oblongifolia seeds is expected to improve the industrial application of crude protein substances. More studies to elaborate the use of this protein mixed with other food materials and their effects on consumer acceptability are needed in future work as recommended point of view.

\section{ACKNOWLEDGEMENTS}

The authors gratefully acknowledged the role and supports of the staff of Sudanese Standards and Metrology Organization (SSMO), Elobeid, the help given by Dr. Ameir of the Central laboratory for Sudan of Ministry of Higher Education during amino acids analyses were highly appreciated.

\section{REFERENCES}

Ahmed MA. 2014. The investigate the quality Aspect from C.brocchiana seeds, and study their nutritional value, Food Science \& Technology Department, College of Agricultural Studies, Sudan University of Science and Technology, Khartoum North, Sudan

Ahmed MA, Mariod AA, Hussein IH, Kamal-Eldin A. 2014. Review: Biochemical composition and medicinal uses of Chrozophora genus, Int J Pharm Rev Res 4(4): 227-232.

AOAC. 2005. Official Methods of Analysis, 17th ed. Association of Official Analytical Chemists, Virginia, USA.

AOCS. 1993. Official Methods and Recommended Practices of the American Oil Chemists' Society, 5th ed. Official method Cc 13b-45, reapproved (2000). AOCS, Champaign, IL.

Beuchat LR. 1977. Functional and electrophoretic characteristics of succinylated peanut flour protein, J Agric Food Chem 25: 258-261. DOI: $10.1021 /$ jf60210a044

Bugis HB. 2009. Supplementation of Some Food Product with Sweet Lupin Powder. University of Umm Al-Qura. Makaa, Saudi Arabia.

Chandi GK,Sogi DS. 2007. Functional properties of rice bran protein concentrate. J Food Eng 79: 592-597. DOI: 10.1016/j.jfoodeng.2006.02.018

Du M, Xie J, Gong B, Xu X, Tang W, Li X. 2018. Extraction, physicochemical characteristics and functional properties of Mung bean protein. Food Hydrocolloid 76 (SupplC): 131-140. DOI: 10.1016/j.foodhyd.2017.01.003

FAO. 1981. Amino Acid Content of Food and Biological Data on Proteins. A report of FAO/UN Joint Committee: Rome, Italy

Galal M, Adam SE. 1988. Experimental Chrozophora plicate poisoning in goats and sheep. Vet Hum Toxicol 30: 447-452.

Jasim MA. 1983. Function Plastein from Fish Waste. [Dissertation]. Loughborough University of Technology, England.

Jyothirmayi T, Prabhakara RPG, Walde SG. 2006. Nitrogen extractability and functional properties of defatted Erythrina variegata Flour. Food Chem 96: 242-247. DOI: 10.1016/j.foodchem.2005.02.023

Kamel MR, Nafady AM, Hassanein AM, Haggag EG. 2018. Chrozophora oblongifolia aerial parts: assessment of antioxidant activity, 
hepatoprotective activity and effect on hypothalamic gonadal axis in adult male rats. J Adv Pharm Res 2 (1): 56-62. DOI 10.21608/aprh.2018.4881

Kato A, Lee Y, Kobayashi K. 1989. Determination and functional properties of food proteins by the treatment with immobilized chymotrypsin at alkaline $\mathrm{pH}$. J Food Sci 54: 1345-1349. DOI: 10.1111/j.1365-2621.1989.tb05988.x

Makri E, Papalamprou E, Doxastakis G. 2005. Study of functional properties of seed storage proteins from indigenous European legume crops (lupin, peas, broad bean) in admixture with polysaccharides. Food Hydrocolloids 19: 583-594. DOI: 10.1016/j.foodhyd.2004.10.028

Masood SB, Rizwana B. 2010. Nutritional and functional properties of some promising legumes protein isolates. Pak J Nutr 9 (4): 373-379. DOI: 10.3923/pjn.2010.373.379

Moharram YG, Rahma EH, Mostafa MM, Messalam SF. 1984. Utilization of tomato cannery wastes (seeds) in food purposes. Minufiya J Agric 8: 291-307.

Monteiro PV, Prakash V. 1994. Effect of proteases on arachin, conarachin I and conarachin II from peanut (Arachis hypogaea L.). J Agric Food Chem 42: 268-273. DOI: 10.1021/jf00038a008
Mossé J. 1990. Nitrogen to protein conversion factor for ten portions of cereal and six legumes or oil seeds. A reappraisal of its definition and determination. Variation according to species and to seed protein content. J Agric Food Chem 38: 18-24. DOI: 10.1021/jf00091a004

Okaka JC, Potter NN. 1977. Functional properties of cowpea-wheat flour blend in bread making, Food Sci 42: 828-833. DOI: 10.1111/j.13652621.1977.tb12614.x

Rahma EH, Dudek S, Mothes R, Gornitz E and Schwenke KD. 2002. Physicochemical characterization of mug bean (Phaseolus aureus) protein isolates. J Sci Food Agric 80: 477-483. DOI: 10.1002/(SICI)1097-0010(200003)80:4<477::AIDJSFA553>3.0.CO;2-0

Sathe SK, Deshpande SS, Saunkhe DK. 1982. Functional properties of winged bean (Psophocarpus tetragonolobus L. DC) proteins. J Food Sci 47: 503-509. DOI: 10.1111/j.1365-2621.1982.tb10112.x

Yeoh HH, Truong VD. 1996. Protein contents, amino acid compositions and nitrogen-to-protein conversion for cassava roots. J Sci Food Agric 70: 51-54. DOI: 10.1002/(SICI)1097-0010(199601)70:1<51::AIDJSFA463>3.0.CO;2-W

Yi-Shen Z, Shuai S, Fitzgerald R. 2018. Mung bean proteins and peptides: nutritional, functional and bioactive properties. J Food Nutr Res 62. DOI: $10.29219 /$ fnr.v62.1290. 